\title{
Studies on the Cheese Flavors
}

\section{Changes of Volatile Carbonyl Compounds during Ripening of Cheese Curd by Aspergillus oryzae chosen $B$}

\author{
Takeo Nakanishi and Yuji NaKazawa \\ (Laboratory of Chemistry and Technology of Animal Products, Faculty of Agriculture, \\ Tohoku University, Sendai, Japan) \\ (Received for Publication on March 22, 1965)
}

In the previous papers of this series ${ }^{9-11}$, formation of volatile free fatty acids and volatile sulphur compounds during ripening of cheese curd by Aspergillus oryzae chosen $B$ were described. Only a little quantities of these compounds were sufficient to cause characteristic flavors of this cheese. During the past few years, carbonyl compounds also have been detected in the matured other cheeses and volatile carbonyl compound(s) (VCC) have been associated directly with characteristic cheese flavor ${ }^{8,14)}$. The present paper is a report on the change of VCC during ripening of cheese curd by Asp. oryzae chosen B. Especially, effects of fat content and starter microbe on formation of VCC were studied.

\section{Materials and Methods}

1. Cheese Samples

Preparation of the ripened cheese curd was based on the procedure reported previously ${ }^{9-11}$.

2. Analytical Methods

(a) The chemical composition

The contents of fat, moisture, ash, nitrogenous compounds, and acidity in cheese were analyzed by the general methods ${ }^{31}$.

(b) Isolation of volatile carbonyl compound(s) (VCC) from cheese

The method reported by Matsuoka et al. ${ }^{8)}$ was modified to measure the quantity of VCC. One hundred $\mathrm{g}$ of cheese sample was shredded into one liter flask containing $200 \mathrm{~m} l$ of distilled water and the mixture was stean distilled $230 \mathrm{~m} l$ of steam distillate was led directly into $50 \mathrm{~m} l$ of 2,4-dinitrophenylhydrazine solution $(1 \mathrm{~g} / 500 \mathrm{~m} l 2 \mathrm{~N} \mathrm{HCl})$ to avoid any loss of the volatiles. The distillate and reagent were held at $45^{\circ} \mathrm{C}$ for $2 \mathrm{hrs}$ and then stored at $0^{\circ} \mathrm{C}$ overnight. The produced 2,4-dinitrophenylhydrazone(s) (D.NPH) were continuously extracted with ethylacetate. The ethylacetate solution was concentrated and stored.

(c) Paper chromatographic separation of DNPH

Separation of the mixed hydrazones was carried out by the method of LynN et al. ${ }^{71}$ and MATsUoKA et al. ${ }^{\text {g' }}$ using 2-phenoxyethanol impregaated papar (Toyoroshi No. 51) as the stationary phase and həptan saturated with 2-phenoxyethanol as the mobile phase.

(d) Identification and quantitative estimation of $\mathrm{VCC}$

Identification and quantitative estimation of each DNPH were carried out by the method of WALKER et al. ${ }^{14)}$ and MATSUoKa et al. ${ }^{81}$ Identification was made by $R$ but 


\section{Stud'es on the Cheese Flavors}

values (distance of movement relative to the hydrazone of butanone-2). In order to record the absorption spectra of individual hydrazones, the separated spots on paper chromatograms were carefully cut out and eluted with $5 \mathrm{ml}$ of ethanol. $0.5 \mathrm{~m} l$ of alcoholic $\mathrm{KOH}(10 \%$ W/V) was added to this solution and their absorption spectra are plotted over the range $300 \sim$ $600 \mathrm{~m} \mu$ using a spectrophotometer.

In order to estimate the individual $\mathrm{DNPH}, 1 \sim 10 \mu l$ of concentrated ethylacetate solution of mixed hydrazones was spotted to a chromatogram paper. Individual hydrazones on the paper chromatogram were eluted with $5 \mathrm{~m} l$ of ethanol. This absorbance at $360 \mathrm{~m} \mu$ was measured using spectrophotometer. The amount of DNPH was measured from the prepared calibration curve.

\section{Experimental Results}

1. Paper Chromatograms, Absorption Patterns, and Properties of DNPH of VCC Isolated from Cheese Curd Ripened by Aspergillus oryzae chosen $B$.

. Paper chromatogram of DNPH of VCC isolated from ripened cheese and authentic DNPH are shown in Fig. 1. Six spots and three spots were detected on paper chromatogram of whole milk curd and skim milk curd after ripening for $192 \mathrm{hrs,} \mathrm{respectively.} \mathrm{Then,} \mathrm{these}$ spots were eluted with ethanol and absorption patterns were obtained as described above (Fig.

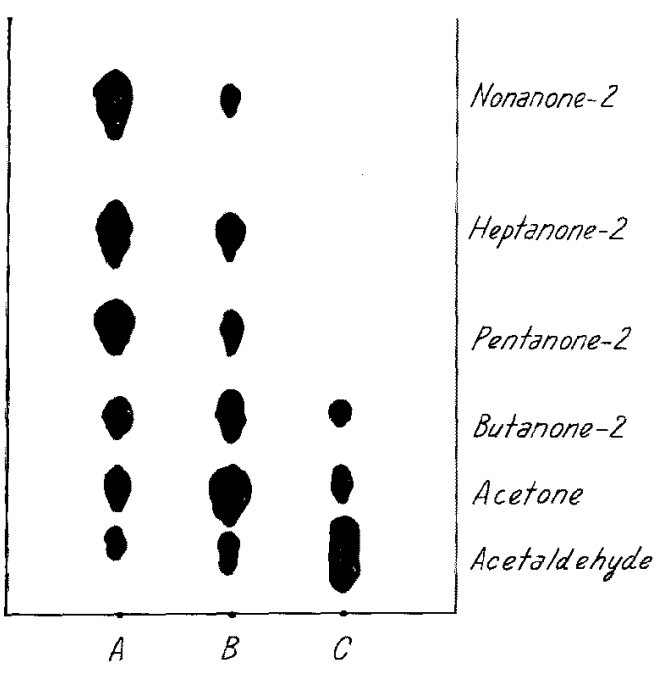

Fig. 1. Paper chromatogram of 2,4-dinitrophenylhydrazones of volatile carbonyl compounds from cheese curd ripened by $A s p$. oryzae chosen $B$.

Solvent system: heptan-2-phenoxyethanol.

A: control (authentic 2,4-DNP hydrazones)

B: $192 \mathrm{hrs}$ aged whole milk cheese curd

C: $192 \mathrm{hrs}$ aged skim milk cheese curd

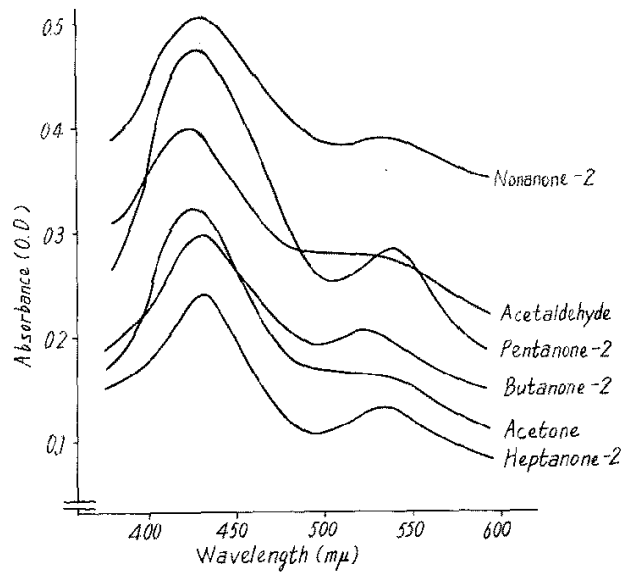

Fig. 2. The absorption patterns of 2,4-dinitrophenylhydrazones of each volatile carbonyl compounds from cheese curd ripened by Asp. oryzae chosen B. (In ethanolic $\mathrm{KOH}$ )

2). Properties of DNPH of VCC isolated from cheese curd ripened by Aspergillus oryzae chosen $B$ are summarized in Table 1 .

As the results, the following six compounds were tentatively identified in the distillates from the ripened cheese curd: acetaldehyde, acetone, butanone-2, pentanone-2, heptanone-2, nonanone-2. In absorption spectra shown in Fig. 2, individual DNPH has two distinctive 
Table 1. Properties of 2,4-dinitrophenylhydrazones of volatile carbonyl compounds isolated from cheese curd ripened by Aspergillus oryzae chosen $B$

\begin{tabular}{|c|c|c|c|c|c|c|c|c|c|c|}
\hline \multirow{3}{*}{$\begin{array}{l}\text { Chro- } \\
\text { mato- } \\
\text { gram } \\
\text { spot }\end{array}$} & \multirow{3}{*}{$\begin{array}{l}\text { Carbonyl } \\
\text { compound }\end{array}$} & \multirow{3}{*}{$\begin{array}{l}R \text { but* } \\
\text { value }\end{array}$} & \multicolumn{4}{|c|}{$\begin{array}{l}\text { Absorption maxima } \\
\text { in ethanolic } \mathrm{KOH}(\mathrm{m} \mu)\end{array}$} & \multicolumn{2}{|c|}{ Colour } & \multirow{3}{*}{\begin{tabular}{|c|} 
First \\
detected \\
(hrs after \\
manufac- \\
ture)
\end{tabular}} & \multirow{3}{*}{$\begin{array}{l}\text { Concen- } \\
\text { tration of } \\
\text { carbonyl } \\
\text { compounds } \\
\text { in cheese } \\
\text { curd } 192 \\
\text { hrs after } \\
\text { munufac- } \\
\text { turing } \\
\text { (p.p.m.) }\end{array}$} \\
\hline & & & \multicolumn{2}{|c|}{ Cheese curd } & \multicolumn{2}{|c|}{ Authentic } & \multirow[b]{2}{*}{$\begin{array}{c}\text { On } \\
\text { paper }\end{array}$} & \multirow{2}{*}{\begin{tabular}{|c|} 
In \\
alkaline \\
solution
\end{tabular}} & & \\
\hline & & & Ma jor & $\begin{array}{l}\text { Sub- } \\
\text { sidi- } \\
\text { ary }\end{array}$ & Major & $\begin{array}{l}\text { Sub- } \\
\text { sidi- } \\
\text { ary }\end{array}$ & & & & \\
\hline I & acetaldehyde & 0.30 & 424 & - & 425 & - & $\begin{array}{l}\text { Red- } \\
\text { brown }\end{array}$ & $\begin{array}{l}\text { Red- } \\
\text { brown }\end{array}$ & 0 & 0.40 \\
\hline II & acetone & 0.69 & 428 & - & 430 & 526 & "I & " & 0 & 2.43 \\
\hline III & butanone-2 & 1.00 & 430 & 528 & 432 & 528 & $" 1$ & $" \prime$ & 0 & 0.35 \\
\hline IV & pentanone-2 & 1.43 & 430 & 528 & 433 & 530 & $\prime \prime$ & $\prime \prime$ & 192 & 0.05 \\
\hline V & heptanone-2 & 2.28 & 434 & 530 & 435 & 528 & $" \prime$ & $\prime \prime$ & 192 & 0.14 \\
\hline $\mathrm{VI}$ & nonanone -2 & 2.84 & 436 & 533 & 434 & 530 & $" \prime$ & $" \prime$ & 192 & 0.20 \\
\hline
\end{tabular}

* Rbut = movement relative to butanone-2 DNP hydrazone.

absorption with major and subsidary maxima. These absorption maxima gave the agreeable results in comparison with authentic derivatives of these compounds. $R$ but values of DNPH from the cheese were identified with the same one of authentic derivatives. The colours of the DNPH of VCC from the cheese both on paper chromatogram and in $10 \%$ alkali show very specific red brown.

2. Development of VCC in Cheese Curd and Effect of Fat Content on Formation of VCC

In the cheese curd ripened by Asp. oryzae chosen $B$, following six VCC were detected, that is, acetaldehyde, acetone, butanone-2, pentanone-2, heptanone- 2 and nonanone- 2 . The average levels of the individual VCC of cheese curd during ripening is given in Table 2. The results were obtained by analysing three series of cheese curd which were made from whole milk, skim milk and half skim milk, respectively.

As shown in Table 2, following six compounds: acetaldehyde, acetone, butanone-2, pentanone-2, heptanone- 2 and nonanone- 2 were contained in whole milk curd after ripening for $192 \mathrm{hrs}$. But, pentanone-2, heptanone-2 and nonanone-2 were not detected in the whole milk cheese curd immediately after making and after ripening for $72 \mathrm{hrs}$. At the start of the ripen'ng and after ripening for $72 \mathrm{hrs}$, acetaldehyde, acetone and butanone-2 were significant in amount. Contents of acetaldehyde, acetone, butanone-2, pentanone-2, heptanone-2 and nonanone-2 were $0.40,2.43,0.35,0.05,0.14$ and 0.20 p.p.m. respectively after ripening for 192 hrs.

Table 2 shows also that pentanone-2, heptanone-2 and nonanone-2 were not detected during ripening of skim milk cheese curd. Acetaldehyde, acetone and butanone-2 were significant in amount at the start of ripening and during ripening of skim milk cheese curd. Contents of acetaldehyde, acetone and butanone-2 were $3.74,0.33$ and 0.18 p.p.m. respectively after ripening for $192 \mathrm{hrs}$.

Half skim milk cheese curd at the start of ripening and during ripening contained acetaldehyde, acetone and butanone-2. But, th's curd did not contain pentanone-2, heptanone-2 and nonanon $2-2$. Contents of acetaldehyde, acetone and butanone-2 were $0.88,0.80$ and 0.33 p.p.m, respectively after ripening for $192 \mathrm{hrs}$.

3. The Contribution of Starter Microbe to the Development of VCC 
Table 2. Changes of volatile carbonyl compounds in cheese curd ripened by Asp. oryzae chosen $B$ (p.p.m.)

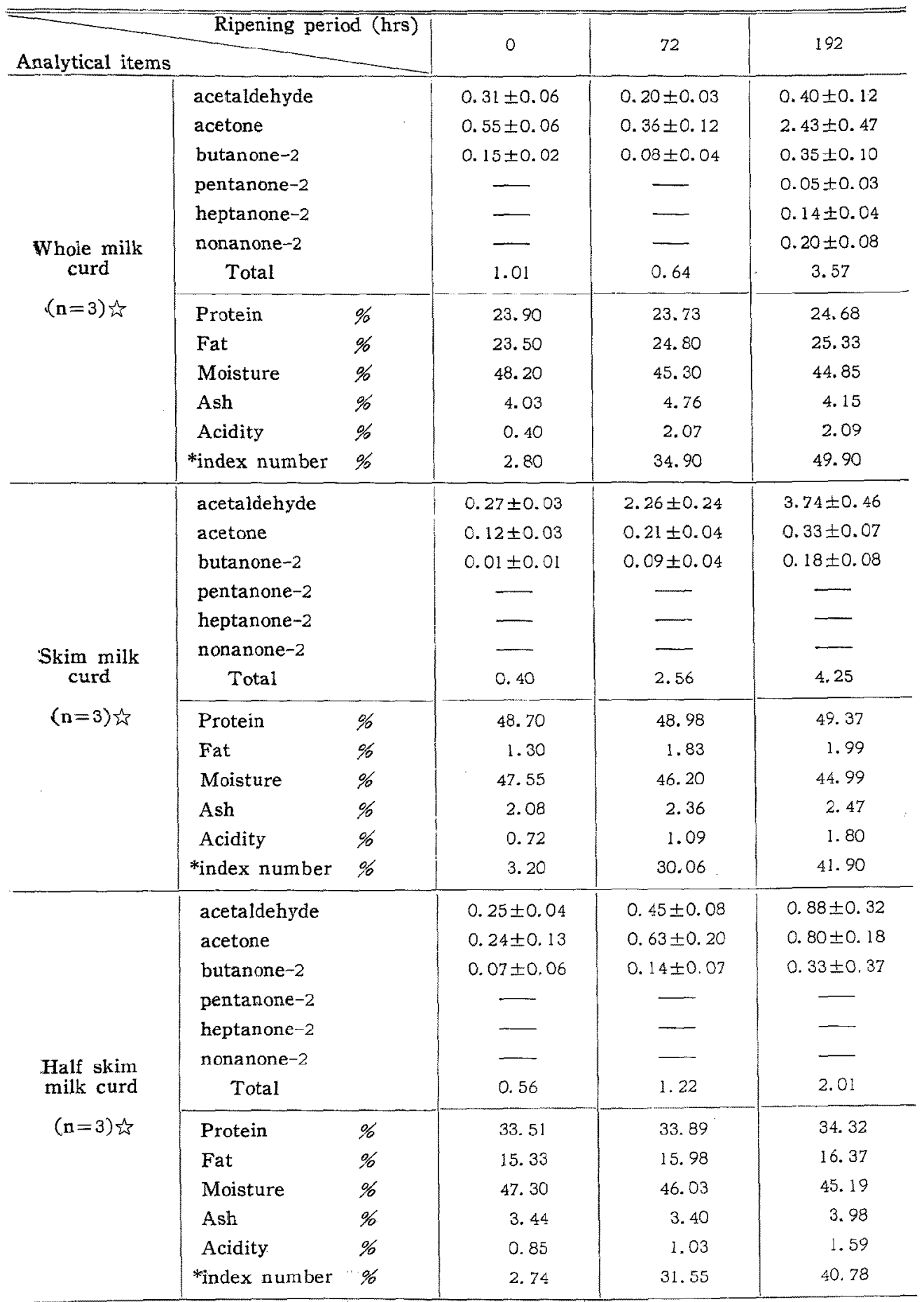

* index number $=$ water soluble $\mathrm{N} /$ total $\mathrm{N} \times 100$.

t numbers of sample analysed. 


\section{NakanishI - NakazaWA}

Table 3. The contribution of starter microbe to the development of yolatile carbonyl compounds (p.p.m.)

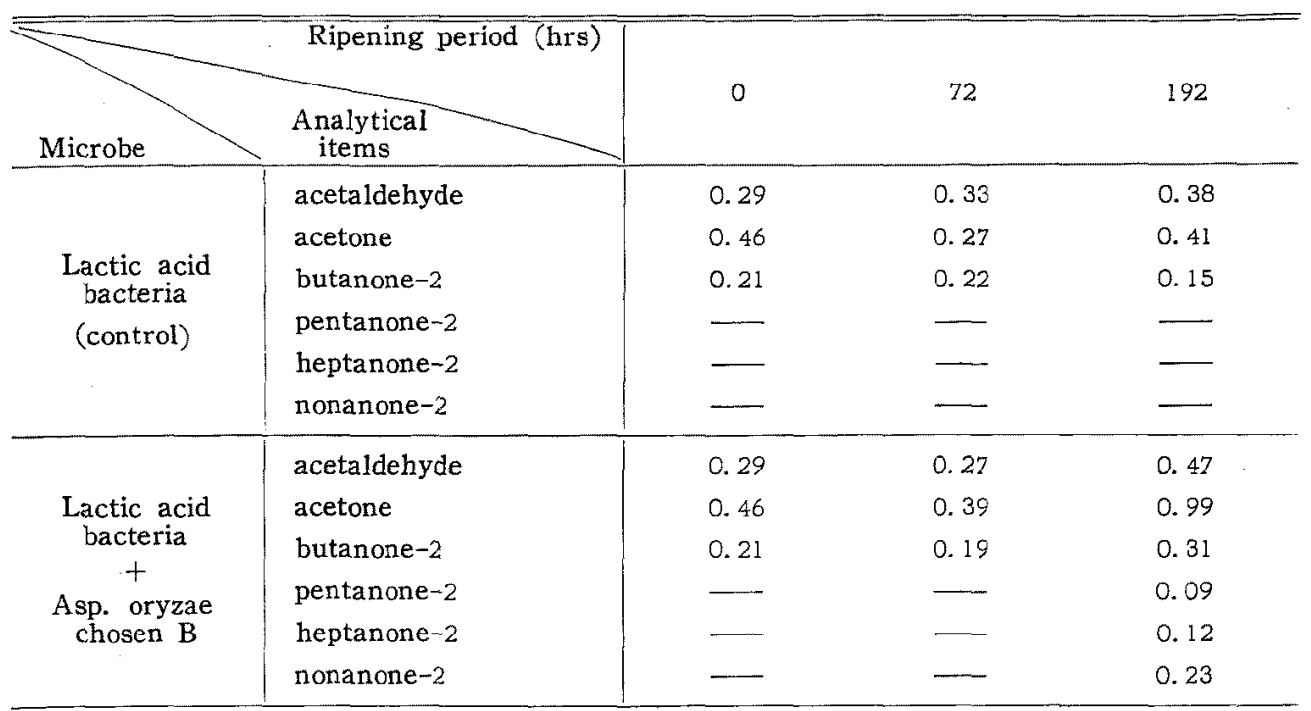

Note: Microbe used (Lactic acid bacteria

Streptococcus lactis

Lactobacillus bulgaricus

Culture medium

Aspergillus oryzae chosen $B$

Whole milk curd

In order to compare the production of VCC, cheese curc ripened with only lactic acid bacteria and that ripened with both lactic acid bacteria and Aspergillus oryzae chosen $B$ were examined.

The change of VCC during ripening of whole milk cheese curd are shown in Table 3. As shown in Table 3, acetaldehyde, acetone and butanone-2 were detected at the start of ripening and during the ripening in the cheese curd ripened with only lactic acid bacteria. Pentanone-2, heptanone-2 and nonanone-2 were not detected during the ripening of this cheese curd.

In the cheese curd ripened with both lactic bacteria and Asp. oryzae chosen $B$, acetaldehyde, acetone, butanone-2, pentanone-2, heptanone-2 and nonanone-2 were detected. Content levels of individual VCC of cheese curd ripened with both lactic acid bacteria and Asp. oryzae chosen $B$ were slightly higher than those of cheese curd ripened with only lactic acid bacteria. It is. clear that there is close correlation between the formation of VCC and the kind of stater.

\section{Discussion}

As volatile carbonyl compound(s) (VCC) which are produced during ripening of cheese curd by Aspergillus oryzae chosen $B$, acetaldehyde, acetone, butanone-2, pentanone-2, heptanone-2 and nonanone-2 were detected. These compounds may have the direct relationship to the development of the flavor. Among the flavor components in this cheese, VCC, volatile free fatty acids ${ }^{10)}$ and volatile sulphur compounds ${ }^{11}$ may have some relationship to flavor quality and intensity.

As shown in Table 2, six compounds mentioned above were contained in whole milk cheese curd during ripening. But, pentanone-2, heptanone-2 and nonanone-2 were not detected in 
skim milk cheese curd and half skim milk cheese curd during ripening, and in these cheese curd, acetaldehyde, acetone and butanone- 2 were significant in amount. The difference is clearly attributed to the fact that milk of different fat content is used in the manufacture of this cheese. Th:s finding will present some interesting and important problems.

It has already been demonstrated that the various methyl ketones found in other cheeses. made in aerobic conditions such as Blue cheese are formed by the action of fungal enzymes. on the fatty acids in cheese ${ }^{4,6,14)}$. The acidic carbonyl compounds are intermediate compounds. in the ripening process and are direct precursors of neutral carbonyl compounds. These products are also associated with the oxidation-reduction system of cheese and are influenced by the ripening conditions. This $\beta$-oxdiation mechanism of formation of methyl ketones is. summarized as follows:

$$
\begin{aligned}
& \mathrm{R} \cdot \mathrm{CH}_{2} \cdot \mathrm{CH}_{2} \cdot \mathrm{COOH} \longrightarrow \mathrm{R} \cdot \mathrm{CH}=\mathrm{CH} \cdot \mathrm{COOH} \longrightarrow \mathrm{R} \cdot \mathrm{CHOH} \cdot \mathrm{CH}_{2} \cdot \mathrm{COOH} \longrightarrow \\
& \mathrm{R} \cdot \mathrm{CO} \cdot \mathrm{CH}_{2} \cdot \mathrm{COOH} \longrightarrow \mathrm{R} \cdot \mathrm{CO} \cdot \mathrm{CH}_{8} \text { (one carbon atom less than the parent fatty acid) }
\end{aligned}
$$

In our study, methyl ketones of odd number carbon atoms such as pentanone-2, heptanone-2: and nonanone- 2 would be suggested as the products from free fatty acids in the cheese ${ }^{10}$. Butanone- 2 of even number carbon atoms maybe produced by the decomposition of acethyl methyl carbinol ${ }^{13}$. Acetaldehyde may be produced by strecker degradation ${ }^{6}$ decarboxylation of pyruvic acid, transamination and decarboxylation of alanine, etc.

PATTON $^{12)}$ found that methyl ketones such as heptanone-2, pentanone-2 and acetone occured: in Blue cheeses. Matsuoka et al. ${ }^{87}$ found that acetaldehyde, acetone, butanone-2, pentanone-2, heptanone-2 and nonanone-2 were produced during ripening of the semi-soft white mould cheese. Other studies on VCC have been reported about Cheddar cheese ${ }^{2)}$, Swiss cheese ${ }^{17}$ etc. The kind and different distribution of VCC in various cheeses may be attributed to microflora used, manufacturing conditions, storage conditions etc.

In order to compare the formation of VCC, cheese curd ripened with only lactic acid: bacteria and that ripened with both lactic acid bacteria and $A s p$. oryzae chosen $B$ are examined. As shown in Table 3 , kinds and contents of $\mathrm{VCC}$ at the start of ripening and during the ripening are different. It is clear that formation of methyl ketones such as pentanone-2, heptanone- 2 and nonanone- 2 are influenced by the use of $A s p$. oryzae chosen $B$. In this cheese curd during ripening, Asp. oryzae chosen $B$ plays an important role in the formation of VCC as described above.

\section{Summary}

The purpose of this investigation was to determine the quantitative changes in volatile carbonyl compound(s) (VCC) which are produced during ripening of cheese curd by Aspergillus oryzae chosen $B$. The results obtained were as follows:

(1) By use of paper chromatographic procedures, 2,4-dinitrophenylhydrazone derivatives of VCC were isolated and identified. As the results, the following six compounds were detected from the ripened cheese curd: acetaldehyde, acetone, butanone-2, pentanone-2, heptanone-2 and nonanone-2.

(2) Six compounds mentioned above were produced in whole milk cheese curd during ripening. But, pentanone-2, heptanone-2 and nonanone-2 were not detected in skim milk cheese curd and half skim milk cheese curd, and in these cheese curd, acetaldehyde, acetone and butanone- 2 were significant in amount. 


\section{Nakanishi - NakazaWA}

(3) The kinds and contents of VCC at the start of ripening and during the ripening of cheeses are different. Especially, the formation of methyl ketones such as pentanone-2, heptanone-2 and nonanone-2 is influensed by the use of Aspergillus oryzae chosen $B$.

\section{Acknowledgements}

This work was supported by a Grant in Aid for Scientific Research from the Ministry of Education.

\section{References}

1) BASSETT, E.W. and W.J. HARPER (1958) J. Dairy Sci., $41: 1206$.

2) DAx, E.A. et a1. (1960) J. Dairy Sci., $43: 463$.

3) Department of Agr. Chem., Tokyo Univ. Jikennogeikagaku, (1958) 615.

4) Foster, J.W. (1949) Chemical Activities of Fungi, 556.

5) JACKsON, H.W. and R V. Hussong (1958) J. Dairy Sci, $41: 920$.

6) Keeney, M. and E.A. Day (1957) J Dairy Sci., $40: 874$.

7) Lynn, W.S. et al. (1956) Anal. Chem., $28: 132$.

8) Matsuoka, H. and T. Tsugo (1963) J. Agr. Chem. Soc. Japan, $37: 332$.

9) Nakanishi, T. and Y. NakaZAWA (1963) Jap. J. Dairy Sci., 12 : A-148.

10) NAKanishi, T. and Y. NAKAzAwA (1964) Jap. J. Zootech. Sci., $35: 98$.

11) NaKanishi, T. and Y. NAKazaWA (1965) Jap. J. Zootech. Sci., 36:60.

12) Patton, S. (1950) J. Dairy Sci., $33: 680$.

13) Scarpelitio, R. and F.V. Kostkowski (1962) J. Dairy Sci., $45: 343$.

14) WALKER, J.R.L. et al. (1959) J. Dairy Res., $26: 265$. 


\section{チ一ズの風味成分に関する研究 \\ V. Aspergillus oryzae chosen $B$ によるチーズカード熟成中における} 揮発性カルボニル化合物の消長

\section{中西武雄-中沢勇二}

（東北大学曹学部畜産利用学教案）

Asp. oryzae chosen B によるチーズカード就成中の 揮発性カルボニル化合物の消唇を険討した. とくに，本 報では揮発性カルボニル化合物の生成に対するカード中 の脂肪舍量の影響と使用微生物の効果を検討しだそその 結果は次のと和りである.

（1）チーズから分離した揮発性カルボニル化合物を 2,4-ジニトロフェニルヒドラゾンにして, ペーパークロ マトグラフイーによつて定量した。熟成チーズカード中 《は次の6 軼の化合物が検出された。すなわち，丁た卜 フルデヒド, フセトン, ブタノン-2, ペンタノン-2, 一
プタノンー2 およびノナノン-2 である。

（2）全脂乳カードの熟成中には，前記 6 種の化合物 が榆出ざれた.これに対して，脱脂乳および半脱脂乳力 一ドの熟成中には, ペンタノン-2, ヘプタノン-2 拈よ びノナノン-2 恰出されず，フセトフルデヒド，フセ トンおよびブタノンー2 が検出された。

（3）熟成開始時および熟成中の揮発性カルボニル化 合物の種類と量は異なつて晾り，とくにAsp. oryzae chosen $B$ 定使用すると, ペンタノン-2, ヘプタノンー2 およびノナノンー2 の生成に効果があった。 